\begin{tabular}{|c|c|c|}
\hline \multirow{3}{*}{$\begin{array}{r}\text { Case Reports in } \\
\text { Gastroenterology }\end{array}$} & \multirow{2}{*}{\multicolumn{2}{|c|}{ Case Rep Gastroenterol 2014;8:162-168 }} \\
\hline & & \\
\hline & $\begin{array}{l}\text { DOI: 10.1159/000363374 } \\
\text { Publisned onIne: IVlay 14, } 2014\end{array}$ & $\begin{array}{l}\text { (c) } 2014 \text { S. Karger AG, Basel } \\
1662-0631 / 14 / 0082-0162 \$ 39.50 / 0 \\
\text { www.karger.com/crg }\end{array}$ \\
\hline & \multicolumn{2}{|c|}{$\begin{array}{l}\text { This is an Open Access article licensed under the terms of the Creative Commons } \\
\text { Attribution-NonCommercial } 3.0 \text { Unported license (CC BY-NC) (www.karger.com/OA- } \\
\text { license), applicable to the online version of the article only. Distribution permitted for non- } \\
\text { commercial purposes only. }\end{array}$} \\
\hline
\end{tabular}

\title{
Successful Management of a Colo-Duodenal Fistula in a Patient with Crohn's Disease Using a Double Lumen Gastro-Jejunostomy Tube
}

\author{
Toru Zuiki Yoshiyuki Meguro Hidetoshi Kumano Koji Koinuma \\ Yasuyuki Miyakura Hisanaga Horie Alan T. Lefor Naohiro Sata \\ Yoshikazu Yasuda
}

Department of Surgery, Jichi Medical University, Shimotsuke City, Japan

\section{Key Words}

Double lumen gastro-jejunostomy tube $\cdot$ Percutaneous endoscopic gastrostomy $\cdot$ Right hemi-colectomy

\begin{abstract}
A 41-year-old woman was admitted with upper abdominal pain, vomiting and fever. Abdominal CT scan showed a colo-duodenal fistula with inflammatory thickening of the transverse colon. The patient's general health was poor because of hypoalbuminemia and coagulopathy. Endoscopy showed a fistula at the lower duodenal angle and the stomach was filled with refluxed stool. Ileostomy and percutaneous endoscopic gastrostomy were performed at that time and a double lumen gastro-jejunostomy inserted through the gastrostomy to allow both gastric drainage and distal enteral feeding. Nutrition support was gradually converted from parenteral to enteral feeding. Colonoscopy showed stenosis of the transverse colon with a colo-colonic fistula near the stenosis. Two months later, right hemicolectomy and closure of the colo-duodenal fistula were performed. The resected specimen showed stenosis and a fistula in the transverse colon due to Crohn's disease. The colocolonic fistula was present and the colo-duodenal fistula had almost closed due to fibrosis. The postoperative course was uneventful and the patient was discharged after administration of infliximab. Use of a double lumen gastro-jejunostomy tube was effective in improving the patient's general condition. This therapeutic strategy allowed the safe conduct of major resection in a high-risk patient.

(c) 2014 S. Karger AG, Basel
\end{abstract}


Zuiki et al.: Successful Management of a Colo-Duodenal Fistula in a Patient with Crohn's Disease Using a Double Lumen Gastro-Jejunostomy Tube

\section{Introduction}

Crohn's disease can result in fistula formation in the small intestine or other segment of the gastrointestinal tract and may be difficult to treat. A colo-duodenal fistula is relatively rare. Klein et al. [1] described $8(0.5 \%)$ of 1,480 patients with Crohn's disease with duodenal fistulae. Michelassi et al. [2] reported entero-duodenal fistulae in 14 (5\%) of 290 operated lesions among 222 patients with Crohn's disease. Pichney et al. [3] reviewed 56 cases of colo-duodenal fistulae in patients with Crohn's disease. In Japan, Noda et al. [4] reported two operated cases of colo-duodenal fistulae in patients with Crohn's disease and reviewed 15 previously reported cases. Most patients with Crohn's disease who develop colo-duodenal fistulae will require surgical treatment, which may be difficult to manage in patients in overall poor condition. We report a case of colo-duodenal fistula between the hepatic flexure of the colon and the inferior duodenal angle induced by inflammatory stenosis of the transverse colon. We performed endoscopic gastrostomy and inserted a double lumen gastro-jejunostomy tube for simultaneous gastric decompression and distal enteral feeding. Resection was then performed safely after improvement in the patient's nutritional status.

\section{Case Report}

A 41-year-old woman was admitted with abdominal pain, vomiting and fever. Four years prior to admission, she was seen at another clinic with the same symptoms and underwent colonoscopy. Inflammatory bowel disease was suspected but not definitively diagnosed. Prednisolone and mesalazine were administered occasionally, but not on a regular basis. She had no remarkable family history.

The patient was $161 \mathrm{~cm}$ tall and weighed $46 \mathrm{~kg}$, with a body mass index of 17.7. Physical examination showed a temperature of $38^{\circ} \mathrm{C}$ and epigastric tenderness. Laboratory data were

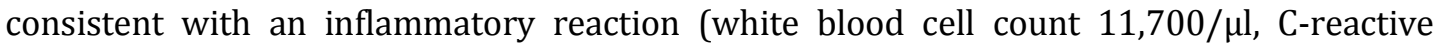
protein $7.93 \mathrm{mg} / \mathrm{dl}$ ), hypoalbuminemia (serum albumin $1.9 \mathrm{~g} / \mathrm{dl}$ ) and coagulopathy (prothrombin time 57.9\%, activated partial thromboplastin time $47.7 \mathrm{~s}$ ). Tumor markers were within normal limits (CEA $1.2 \mathrm{ng} / \mathrm{ml}$, CA19-9 $4 \mathrm{U} / \mathrm{ml}$ ).

Abdominal CT scan revealed inflammatory thickening of the transverse colon and a colo-duodenal fistula at the hepatic flexure (fig. 1). Endoscopy showed a fistula in the duodenum and a dilated stomach filled with refluxed stool. A colo-duodenal fistula between the lower duodenal angle and the hepatic flexure was demonstrated by contrast X-ray during endoscopy (fig. 2). The patient was admitted to the gastroenterology service and treated with antibiotics, no oral intake and intravenous hyperalimentation. The central venous catheter was removed soon after placement because of continuous fever, and her nutritional status did not improve. The fever persisted for 2 weeks despite routine management and she was referred for surgical treatment of the inflammatory lesion in the transverse colon.

Right hemi-colectomy with resection of the fistula was considered too invasive given her poor overall health as illustrated by hypoalbuminemia and coagulopathy. A temporary ileostomy was planned to reduce the amount of refluxed stool in the duodenum, with a gastrostomy for drainage. Ileostomy was made using a small incision under general anesthesia, and percutaneous endoscopic gastrostomy was performed at the same time. The ileostomy was created $20 \mathrm{~cm}$ from the cecum. After percutaneous gastropexy using a Funada-style kit, endoscopic gastrostomy was performed using the direct method (Direct Ideal PEG, Olympus, Tokyo, Japan). Three days later, the gastrostomy button was changed to 
Zuiki et al:: Successful Management of a Colo-Duodenal Fistula in a Patient with Crohn's Disease Using a Double Lumen Gastro-Jejunostomy Tube

a double lumen gastro-jejunostomy tube (MIC-TJ, Kimberly-Clark, Roswell, Ga., USA) using a small-caliber endoscope and a guide wire. The tube was advanced to the jejunum and elemental diet given through the distal lumen of the tube. Gastric contents with refluxed stool were drained from the proximal lumen. Colonoscopy was performed on postoperative day 21, which showed a tight stenosis of the transverse colon. A colo-colonic fistula was revealed near the stenosis by contrast X-ray during colonoscopy.

68 days later, the patient's nutritional status and general condition had improved (serum albumin $3.3 \mathrm{~g} / \mathrm{dl}$, prothrombin time $81.4 \%$, body weight $51 \mathrm{~kg}$ ), and a right hemicolectomy with resection of the fistula was performed. The terminal ileum with the ileostomy and thickened transverse colon were resected en bloc. Reconstruction was performed using a functional end-to-end anastomosis between the ileum and transverse colon using a linear stapler. The fistula in the duodenum was treated with suture closure. The omentum was placed between the duodenum and the anastomosis to minimize refistulization. The resected specimen revealed thickening and stenosis of the transverse colon. The colo-colonic fistula was present, and the colo-duodenal fistula had almost closed due to fibrosis. Epithelioid cell granulomas and Langerhans giant cells were seen in the mucosa.

The postoperative course was uneventful and the patient resumed oral intake. The double lumen gastro-jejunostomy tube was removed on postoperative day 20 . Infliximab was administered on postoperative day 34 and the patient discharged on postoperative day 38.

\section{Discussion}

The timing of surgery for patients with fistulae secondary to Crohn's disease is an important issue. Gisbert and Gomollon [5] described that internal fistulae alone are not an indication for surgery, unless they exclude a large segment of the intestine and are symptomatic, as is typical with ileo-sigmoid or gastro-colic fistulae. Fistulae should be managed mainly by enteral feeding and appropriate medication, but surgery should be considered in severely ill patients or those who fail to improve with medical therapy. A coloduodenal fistula is thought to be an absolute indication for surgery [2]. In this patient, there was no other lesion, and it was felt that stenosis of the transverse colon and extension of inflammation was the cause of the colo-duodenal fistula. There was a great deal of stool refluxing into the duodenum, and the patient complained that abdominal pain was worsened after starting an elemental diet through the naso-gastric tube. At that point, it was felt that non-operative treatment would not result in clinical improvement.

Operative repair of colo-duodenal fistula has been reported, with resection of the stenotic lesion and closure of the fistula being adequate $[3,6]$. There is concern about leakage at the site of anastomosis in the duodenum and refistulization. In patients with a large defect in the duodenal wall after resection of the fistula, reconstruction of the duodeno-jejunal anastomosis has been reported [7]. Rutgeerts et al. [8] reported that the ileocolic anastomosis caused stenosis in $72 \%$ of patients after curative surgery. Based on these reports, a temporary ileostomy was performed emergently for the present patient and resection of the ileostomy planned for a later date.

We planned to administer an elemental diet until the patient's nutritional status improved, enabling her to withstand major resection. Using a double lumen tube was expected to make it possible to perform gastric drainage and enteral feeding through the same gastrostomy site. During the subsequent resection, we found that the colo-duodenal fistula 
Zuiki et al.: Successful Management of a Colo-Duodenal Fistula in a Patient with Crohn's Disease Using a Double Lumen Gastro-Jejunostomy Tube

was almost closed due to fibrosis, and the fistula site was resected easily without damage to the duodenal wall. At the time of reconstruction, a functional end-to-end anastomosis was performed. Since recurrent fistulization has been reported in up to $30 \%$ of patients after surgery, omental interposition was used to protect against this complication $[4,6,7]$.

The percutaneous endoscopic gastro-jejunostomy double lumen tube was originally developed for patients with gastroesophageal reflux to change gastrostomy to jejunostomy. This tube allows simultaneous drainage through the proximal lumen and enteral feeding through the distal lumen (fig. 3). Taking advantage of this characteristic, we previously used this double lumen tube in patients with pyloric obstruction or afferent loop syndrome [9]. Recently, we insert the double lumen tube in one step with the following procedure: perform an endoscopic gastropexy using a Funada-style kit, insert a dilator with the external sheath into the stomach, remove the dilator leaving the sheath, insert a small-diameter endoscope through the sheath and carry the guide wire to the jejunum, then pass the double lumen tube into the jejunum along the guide wire through the sheath. This procedure is effective in patients with pyloric obstruction due to advanced gastric cancer which is unresectable and makes it impossible to create a gastro-jejunal bypass. In the present patient, gastric drainage and enteral feeding were performed effectively in the perioperative period using the single tube. Lee and Schraut [6] also recommended transgastric placement of a duodenal tube across the duodenal closure for postoperative enteral alimentation.

Based on a literature search, this is the first report of the use of a double lumen gastrojejunostomy tube in a patient with a colo-duodenal fistula secondary to Crohn's disease. Emergent operation in patients with Crohn's disease may require a two-stage procedure [10]. Some patients require multiple operations because of anastomotic leakage or recurrent disease. Ileostomy was selected in this patient with poor overall health to avoid the risk of an anastomotic leak after major resection. However, placement of a double lumen gastrojejunostomy tube early in the course of non-operative treatment may allow less invasive treatment, obviating the need for an ileostomy.

In summary, the use of a double lumen gastro-jejunostomy tube enabled this patient to improve her overall physiologic status and successfully undergo major resection without subsequent complications.

\section{References}

1 Klein S, Greenstein AJ, Sachar DB: Duodenal fistulas in Crohn's disease. J Clin Gastroenterol 1987;9:46-49.

$\longrightarrow 2$ Michelassi F, Stella M, Balestracci T, Giuliante F, Marogna P, Block GE: Incidence, diagnosis, and treatment of enteric and colorectal fistulae in patients with Crohn's disease. Ann Surg 1993;218:660-666.

-3 Pichney LS, Fantry GT, Graham SM: Gastrocolic and duodenocolic fistulas in Crohn's disease. J Clin Gastroenterol 1992;15:205-211.

4 Noda E, Meada K, Inoue T, Nishihara T, Yashiro M, Yamada Y, et al: Two cases report of Crohn's disease that formed colonic-duodenal fistula (in Japanese). Jpn J Gastroenterol Surg 2006;39:608-613.

5 Gisbert JP, Gomollon F: Timing of surgery in Crohn's disease: a key issue in the management. World J Gastroenterol 2008;14:5532-5539.

-6 Lee KKW, Schraut WH: Diagnosis and treatment of duodenoenteric fistulas complicating Crohn's disease. Arch Surg 1989;124:712-715.

7 Wilk PJ, Fazio V, Turnbull RB: The dilemma of Crohn's disease: ileoduodenal fistula complicating Crohn's disease. Dis Colon Rectum 1977;20:387-392.

8 Rutgeerts P, Geboes K, Vantrappen G, Kerremans R, Ceonegrachts JL, Coremans G: Natural history of recurrent Crohn's disease at the ileocolonic anastomosis after curative surgery. Gut 1984;25:665-672.

-9 Haruta H, Hosoya Y, Kurashina K, Zuiki T, Ui T, Yano T, et al: Direct percutaneous endoscopic duodenostomy using double-balloon endoscopy in a patient with afferent loop syndrome after Roux-en-Y reconstruction: a case report (in Japanese). Gastroenterol Endosc 2012;54:3804-3811.

10 Greenstein AJ, Sachar DB, Mann D, Lachman P, Heimann T, Aufses AH Jr: Spontaneous free perforation and perforated abscess in 30 patients with Crohn's disease. Ann Surg 1987;205:72-76. 


\begin{tabular}{ll|l} 
Case Reports in & \multicolumn{2}{l}{} \\
\cline { 2 - 3 } Gastroenterology & Case Rep Gastroenterol 2014;8:162-168 \\
\cline { 2 - 3 } & DOI: 10.1159/000363374 & $\begin{array}{l}\text { ○ 2014 S. Karger AG, Basel } \\
\text { www.karger.com/crg }\end{array}$ \\
\hline Zuiki et al.: Successful Management of a Colo-Duodenal Fistula in a Patient with
\end{tabular}

Zuiki et al.: Successful Management of a Colo-Duodenal Fistula in a Patient with Crohn's Disease Using a Double Lumen Gastro-Jejunostomy Tube

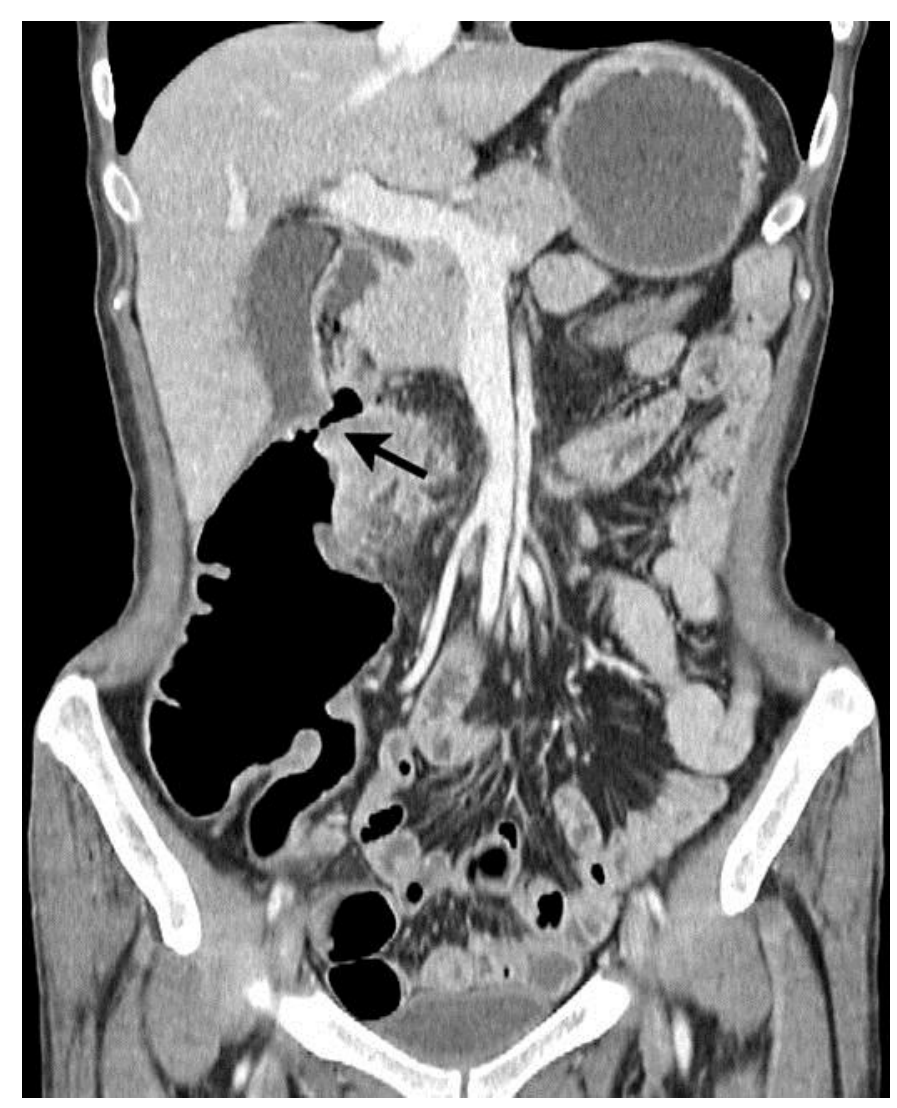

Fig. 1. Abdominal CT scan showing the colo-duodenal fistula on coronal view (arrow). 


\begin{tabular}{|c|c|c|}
\hline \multirow{3}{*}{$\begin{array}{r}\text { Case Reports in } \\
\text { Gastroenterology }\end{array}$} & \multirow{2}{*}{\multicolumn{2}{|c|}{ Case Rep Gastroenterol 2014;8:162-168 }} \\
\hline & & \\
\hline & DOI: $10.1159 / 000363374$ & $\begin{array}{l}\text { (c) } 2014 \text { S. Karger AG, Basel } \\
\text { www.karger.com/crg }\end{array}$ \\
\hline
\end{tabular}

Zuiki et al.: Successful Management of a Colo-Duodenal Fistula in a Patient with Crohn's Disease Using a Double Lumen Gastro-Jejunostomy Tube

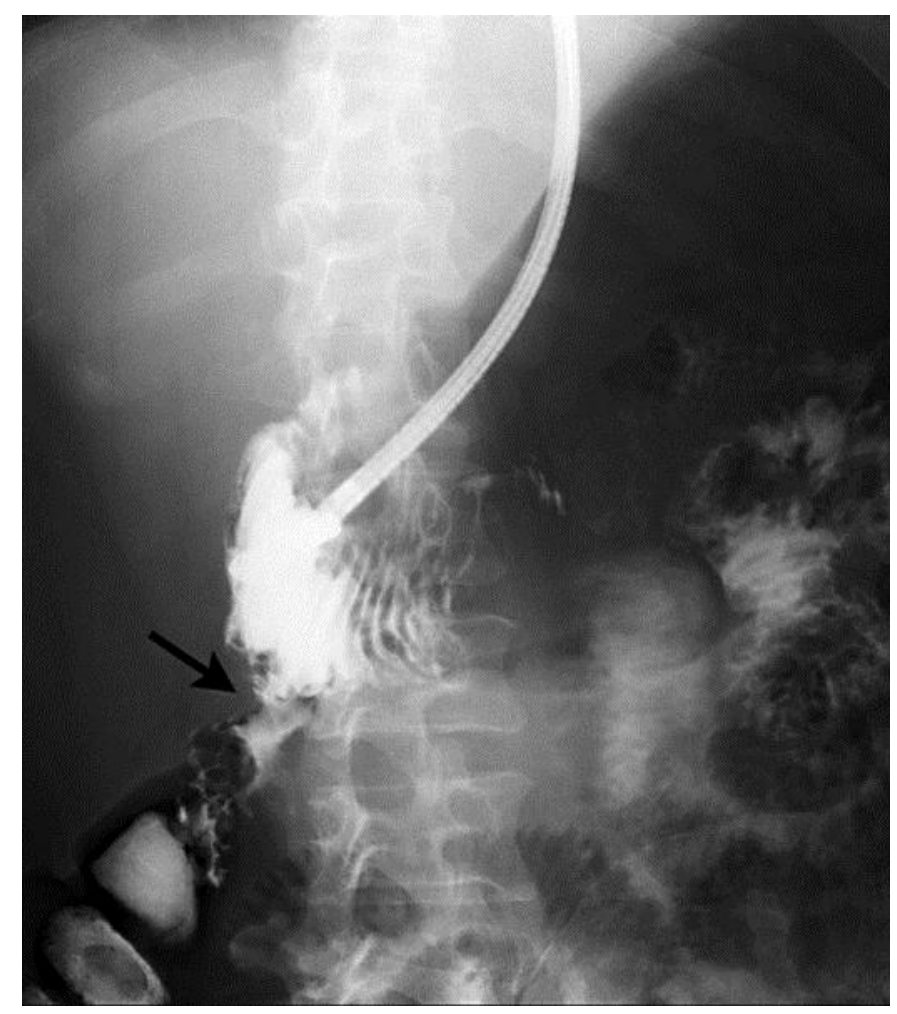

Fig. 2. Contrast radiography demonstrated flow through the colo-duodenal fistula (arrow). 


\begin{tabular}{|c|c|c|}
\hline \multirow{3}{*}{$\begin{array}{r}\text { Case Reports in } \\
\text { Gastroenterology }\end{array}$} & \multirow{2}{*}{\multicolumn{2}{|c|}{ Case Rep Gastroenterol 2014;8:162-168 }} \\
\hline & & \\
\hline & DOI: $10.1159 / 000363374$ & $\begin{array}{l}\text { (c) } 2014 \text { S. Karger AG, Basel } \\
\text { www.karger.com/crg }\end{array}$ \\
\hline
\end{tabular}

Zuiki et al.: Successful Management of a Colo-Duodenal Fistula in a Patient with Crohn's Disease Using a Double Lumen Gastro-Jejunostomy Tube

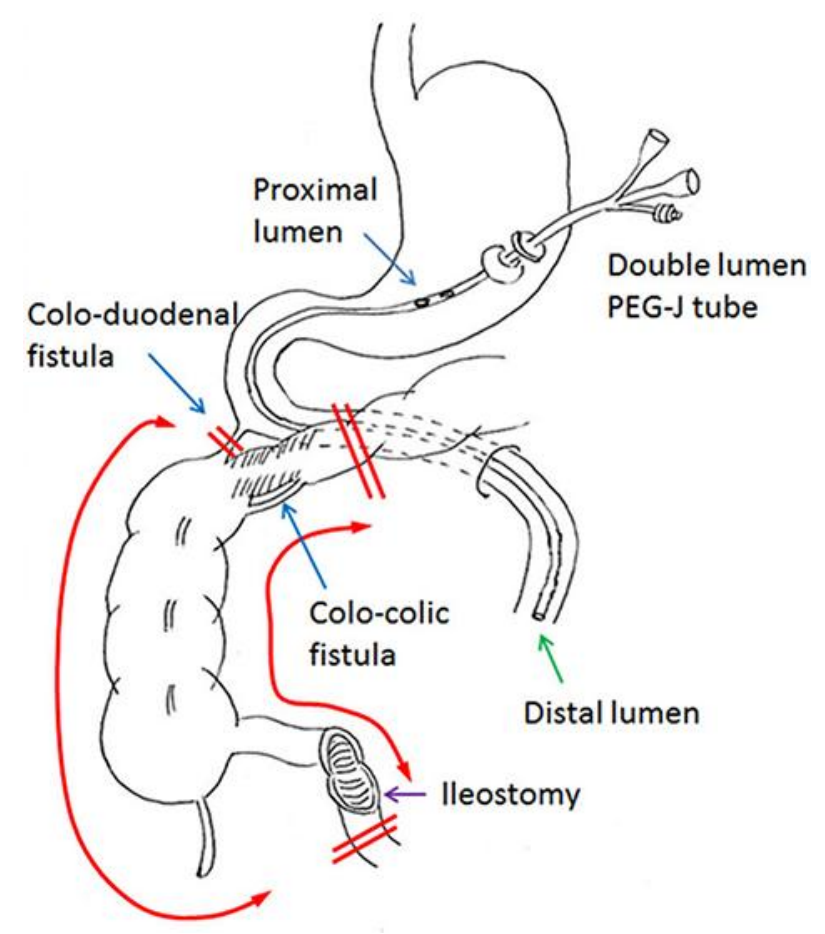

Fig. 3. Schema showing the gastro-jejunostomy tube, the location of two fistulae and the procedure performed at the second operation (right hemi-colectomy). 